\title{
Influence of hydro-sedimentary factors on mollusc death assemblages in a temperate mixed tide-and-wave dominated coastal environment: Implications for the fossil record
}

\author{
Clément Poirier ${ }^{\mathrm{a}, ~}{ }^{*}$, Pierre-Guy Sauriau ${ }^{\mathrm{a}, \mathrm{b}}$, Eric Chaumillon ${ }^{\mathrm{a}}$ and Xavier Bertin ${ }^{\mathrm{a}, \mathrm{c}, 1}$
}

\author{
a LIENSs (LIttoral, ENvironnement, Sociétés), Université de La Rochelle, CNRS, 2 rue Olympe de Gouges, 17000 \\ La Rochelle, France \\ ${ }^{\mathrm{b}}$ ELA (Environnement Littoral Atlantique), Ifremer, CNRS, place Gaby Coll, BP 5, 17137 L'Houmeau, France \\ ${ }^{\mathrm{c}}$ Estuaries and Coastal Zones Division, National Laboratory of Civil Engineering, Avenida do Brasil 101, 1700-066 \\ Lisbon, Portugal \\ ${ }^{1}$ Present address. LIENSs (LIttoral, ENvironnement, Sociétés), Université de LaRochelle, CNRS, 2rue Olympe \\ de Gouges, 17000 La Rochelle, France.
}

\author{
*: Corresponding author : Clément Poirier, Tel.: +33 546507644; fax: +33 546458274, email address : \\ clement.poirier@univ-Ir.fr \\ pierre.guy.sauriau@ifremer.fr (P.-G.Sauriau), eric.chaumillon@univ-Ir.fr (E. Chaumillon), xavier.bertin@univ-Ir.fr \\ (X. Bertin).
}

\begin{abstract}
:
Mollusc death assemblages were recovered in 98 subtidal sampling stations on the seafloor of the shallow Pertuis Charentais Sea (Atlantic coast of France). Taxonomic composition and spatial distribution of death assemblages were investigated, as well as their response to sediment grain size (field data), bottom shear stress (coupled tide and wave hydrodynamic modelling), and sediment budget (bathymetric difference map). Results showed that molluscs are likely to be reliable paleoenvironmental indicators since death assemblages were able to acquire ecological changes within years (decadal-scale taphonomic inertia), and live-dead agreement inferred from existing data on living benthic communities was high, except close to river mouths and intertidal mudflats that provide terrestrial and intertidal species to subtidal death assemblages, respectively. Taxonomic composition of these within-habitat death assemblages strongly depended on sediment grain size and bottom shear stress, similarly to living subtidal communities. Post-mortem dispersal of shells, owing to relatively low bottom shear stress in the area, was only of a few 10s to 100s of meters, which shows that death assemblages preserved environmental gradients even at a fine spatial scale. Sediment budget had also a significant influence on death assemblages. Thick-shelled epifaunal species were correlated with erosion areas on one side, and thin-shelled infaunal species with deposition on the other, showing that mollusc fossil assemblages could be used as indicators of paleo-sedimentation rate. This new proxy was successfully tested on a previously published Holocene mollusc fossil record from the same area. It was possible to refine the paleoenvironmental interpretation already proposed, in accordance with existing stratigraphic and sedimentological data.
\end{abstract}

Keywords: Benthos; Estuary; Holocene; Paleoecology; Sediment budget; Taphonomy 


\section{Introduction}

Integrated multi-proxy analyses of Holocene sedimentary records have been used worldwide to describe changes in coastal environments throughout the last millenaries (Anderson et al., 2007). Many of these studies have used fossil remains to provide high-resolution paleoenvironmental reconstructions. Molluscs have been successfully used as paleoindicators of bathymetry, salinity, hydrodynamics, or sediment supply (e.g. Taldenkova et al., 2005; Zinke et al., 2005, Gruet and Sauriau, 1994; Allard et al., 2008; Poirier et al., 2009). Mollusc fossil remains are also frequently used as material for radiocarbon dating of Holocene sedimentary records (e.g. Colman et al., 2002).

Paleoenvironmental reconstructions are either qualitative, or more recently quantitative with the development of transfer functions that often deal with microfossils such as foraminifers (e.g. Rossi and Horton, 2009). Since both approaches are based on the principle of uniformitarism, they require a good knowledge on the ecology of present day communities. In the case of molluscs, knowledge of environmental preferences is usually derived from largescale compilations of data about the distribution of species along latitude, temperature, salinity or depth gradients (e.g., for western Europe, Tebble, 1966; Graham, 1988; Peacock, 1993), and from local surveys of benthic macrofauna that assess local relationships between communities and environmental factors (Sanders, 1958; Warwick and Uncles, 1980; Sauriau et al., 1989).

Before being incorporated into the fossil record, dead mollusc shells accumulate in a sediment sub-surface layer called the Taphonomically Active Zone (Davies et al., 1989). In this transition area from biosphere to lithosphere, both the taxonomic composition and the abundance of mollusc skeletal remains may be modified depending on several factors. According to Kidwell and Bosence (1991), they are controlled by key factors including the supply of shells, the susceptibility of shells to post-mortem modifications, the environment of accumulation that is characterised by biological, chemical and physical processes of postmortem modification (taphonomy, Efremov, 1940) and the rate of net sediment accumulation. This latter process is of prime importance, since it determines time-averaging, i.e. the period during which skeletal remains are exposed to taphonomic processes (Kidwell and Bosence, 1991), prior to final burial into the sedimentary record. All these processes lead to a final mismatch between the composition and structure of the mollusc fossil record and that of its original live community (Kidwell, 2002), potentially causing erroneous paleoenvironmental interpretation from biased fossil assemblages.

A considerable amount of data about mollusc death assemblages is available, regarding "live-dead" agreement (Kidwell, 2002, 2007), differential preservation (Fürsich and Flessa, 1987; Lockwood and Work, 2006), and time-averaging (Kowalewski et al., 1998; Flessa et al. 1993). A wealth of studies have examined the influence of environmental factors on mollusc death assemblages, including bottom facies (Johnson, 1965; Miller, 1988; Zuschin and Oliver, 2003), hydrodynamics (Cadée, 1968; Henderson and Frey, 1986) and sediment disturbance (Aller, 1995). However, most did not fully establish quantitative correlations between environmental factors and the composition and spatial distribution of mollusc death assemblages, and they are usually based on few sampling stations located along transects (with the notable exception of Johnson, 1965; Miller, 1988; and Cadée, 1968). In this study, we report the results of a detailed (systematic grid of 98 sampling stations) study of mollusc death assemblages in a temperate mixed tide-and-wave dominated coastal environment. The aim of this study is to: (1) describe the taxonomic composition and spatial distribution of mollusc death assemblages, (2) describe the response of mollusc death assemblages to hydro-sedimentary factors (sediment grain size, bottom shear stress and sediment budget), (3) identify species that could be used as paleoenvironmental indicators in coastal Holocene sedimentary records, and (4) test the effectiveness of this actuopaleontological approach on a previously published mollusc fossil record from the same area (Poirier et al., 2009). 


\section{Study area}

\subsection{Geomorphology}

The Pertuis Charentais Sea is located along the Atlantic Coast of France, approximately 70 $\mathrm{km}$ northward of the Gironde Estuary (Fig. 1a). The word "pertuis" locally refers to incisedvalley segments (Chaumillon and Weber, 2006) bounded by the Ré and Oléron Islands (Fig. 1b). Both the Pertuis Breton to the north and the Pertuis d'Antioche to the south are approximately $30 \mathrm{~km}$ long and $10 \mathrm{~km}$ wide, and oriented along a NW-SE axis. Their most onshore parts are connected to the Aiguillon Cove (about $50 \mathrm{~km}^{2}$ ) and the Marennes-Oléron Bay (about $200 \mathrm{~km}^{2}$ ). The southern Marennes-Oléron Bay is connected to the Atlantic Ocean by the Maumusson Inlet, which is within the incised valley of the Seudre River (Bertin et al., 2004).

The bathymetry of the Pertuis Charentais Sea can be divided into two domains (Chaumillon and Weber, 2006; Fig. 2a). Westward, it includes the Chevarache Deep (CD, $56 \mathrm{~m}$ below mean sea level, bmsl) and the Antioche Deep (AD, $48 \mathrm{~m} \mathrm{bmsl}$ ) for the Pertuis Breton and the Pertuis d'Antioche, respectively. Eastward, gentle slopes characterised the inner shallow domains (from about -15 to $-4 \mathrm{~m}$ bmsl), namely the Breton Inner Domain (BID) and the Antioche Inner Domain (AID). Bays are characterised by extensive intertidal mudflats, which represent $67 \%$ of the Aiguillon Cove and $60 \%$ of the Marennes-Oléron Bay. The communication between the Pertuis d'Antioche and the Marennes-Oléron Bay includes the elongated Longe de Boyard (LdB) sandbank (Chaumillon et al., 2008). Tidal channels in the Marennes-Oléron Bay have water depth ranging from about $-20 \mathrm{~m}$ in the Maumusson Inlet to $-5 \mathrm{~m}$ bmsl elsewhere. In the northern part of the bay, the Rade des Trousses (RdT) tidal channel is wide (about $5 \mathrm{~km}$ ), whereas tidal channels are relatively narrow (from about 300 to $900 \mathrm{~m}$ ) in the central and southern parts of the bay.

\subsection{Hydrodynamics and seafloor sediment}

The Pertuis Charentais Sea is a mixed-tide-and-wave dominated system. Tides are semidiurnal, with amplitude ranging from less than $2 \mathrm{~m}$ (neap tides) to more than $6 \mathrm{~m}$ (spring tides). Mean annual offshore swell conditions are characterised by significant wave heights of $1.5 \mathrm{~m}$, periods ranging from 8 to $12 \mathrm{~s}$ coming predominantly from the $\mathrm{W}$ to $\mathrm{NW}$, but winter storms can episodically produce swells larger than $9 \mathrm{~m}$ (Bertin et al., 2008). Wind waves together with tidal currents promote mud resuspension (Raillard and Menesguen, 1994) contributing to high turbidity of shallow waters. Four small coastal rivers (mean water discharge ranging from 2 to $100 \mathrm{~m}^{3} \cdot \mathrm{s}^{-1}$ ) contribute to moderate freshwater input: the Lay River and Sèvre Niortaise River that flow into the Pertuis Breton and Aiguillon Cove respectively, and the Charente River and Seudre River that flow into the Marennes-Oléron Bay (Fig. 1b).

Sediment shows complex distribution patterns on the seafloor (Fig. 2b). The Pertuis Charentais Sea is covered mainly by sandy mud and mud. This mud drape spreads towards the west, infilling the deepest parts of the Chevarache and Antioche Deeps. It is bounded by rocky outcrops covered by discontinuous patches of sand (fine sand to gravel) emplaced on the slopes of the incised valleys. The northern slope of the Chevarache Deep is covered by a vast area of gravel to fine sand, whereas the southern slope is characterised by a complex combination of gravel, sand and muddy sand patches extending within the Breton Inner Domain. Discontinuous sand patches and rocky outcrops occur in the Antioche Inner Domain. The western part of the Marennes-Oléron Bay is composed of mixed sand and mud flats, whereas the eastern part is covered by the mud drape. Tidal channels in the bay are filled mainly with sand. To the south, the Maumusson Inlet is filled with sand and gravel. 


\subsection{Living benthic communities}

Species richness, abundance, biomass and spatial distribution of living infaunal benthic communities have been accurately investigated in the subtidal part of the whole Pertuis Charentais Sea (Hily, 1976) and Marennes-Oléron Bay (Sauriau et al., 1989; de Montaudouin and Sauriau, 2000; Sauriau and Pigeot, in press). These studies confirmed the combined influence of bathymetry and sediment grain size on the taxonomic composition of macrofaunal assemblages, as previously described in the Bay of Biscay (Dauvin, 1997).

The Pertuis Charentais Sea is characterised mainly by a Syndosmya (= Abra) community, which lives in sheltered or estuarine areas, often with a somewhat reduced salinity and on a mixed to muddy bottom rich in organic material (Thorson, 1957). According to Kidwell and Bosence (1991), this is a representative example of "low-density fossil assemblages embedded within a larger homogeneous sedimentary body" that corresponds to "withinhabitat time-averaged assemblages". Mollusc species belonging to the Abra community are mainly infaunal suspension- and/or deposit-feeding bivalves (Sauriau et al., 1989), the most frequent being Abra nitida, Nucula nitidosa, Kurtiella (= Mysella) bidentata, Corbula gibba, and Spisula subtruncata (Table 1). The Abra community transitions gradually into a Tellina community in shallower, sandy areas exposed to wave breaking, where dominant species in this case are the bivalves Tellina tenuis, Tellina fabula, and Donax vittatus (Table 1). On coarser sands, a modified Thorson's Venus community appears, which is dominated by the large, resistant shell bivalve Spisula solida (Table 1).

On intertidal flats and shallow-water environments bound to estuarine conditions, the Abra community is replaced by a Macoma community (Thorson, 1957), which is composed of the deposit-feeder gastropod Hydrobia ulvae and of bivalves such as Macoma baltica, Scrobicularia plana, Cerastoderma edule, and Mytilus edulis (Gouleau, 2000). Contrary to the cockle $C$. edule, which is restricted to mud and sandy mud intertidal flats, the epifaunal blue mussel $M$. edulis colonises hard substrata in both intertidal and subtidal areas. Epifaunal benthic communities of the Pertuis Charentais Sea have received little attention compared to infaunal species. The most common species, apart from Mytilus edulis, are the bivalves Anomia ephippium, Chlamys varia and Aequipecten opercularis (de Montaudouin and Sauriau, 2000).

The Pertuis Charentais Sea is under a strong anthropogenic influence, since it is a major area of shellfish farming in Europe (Goulletquer and Héral, 1997). Reared species include the man-introduced Pacific oyster Crassostrea gigas (locally introduced in 1971; Grizel and Héral, 1991) and Manila clam Ruditapes philippinarum (locally introduced in 1984; Goulletquer, pers. comm., 2010), and the native blue mussel Mytilus edulis. Shellfish farms are spread in the whole area, but mussel farms are particularly abundant wihin the Pertuis Breton and along the Arçay sandspit whereas oyster farms are dominant in the MarennesOléron Bay (Fig. 1b). The Pertuis Charentais Sea is also exposed to the introduction of noncommercial, non-indigenous species (Goulletquer et al., 2002), including molluscs such as the slipper limpet Crepidula fornicata (first reported in 1969, Lubet and Le Gall, 1972), the nassariid gastropod Cyclope neritea (first reported in 1983-1984, Sauriau, 1991), and the oyster drill Pteropurpura (= Ocinebrellus) inornatus (first reported in 1994, Sauriau and Pigeot, in press).

\subsection{Holocene sedimentary records}

The Holocene sedimentary infill of the Pertuis Charentais Sea has been extensively investigated with very high resolution seismic surveys ground-truthed by sediment cores, in the two Pertuis Deeps and Inner Domains (Chaumillon and Weber, 2006), and in the Marennes-Oléron Bay (Chaumillon et al., 2004; Bertin and Chaumillon, 2005; Billeaud et al., 2005; Chaumillon and Weber, 2006; Allard et al., 2008, 2010). Mollusc fossil remains have been successfully used to describe the succession of paleoenvironments in the Marennes- 
Oléron Bay during the last 8000 years BP (Allard et al., 2008; Poirier et al., 2009). A major environmental change occurred in the whole area at $630 \pm 30$ uncalibrated years BP (radiocarbon dating of a mollusc shell; Allard et al., 2008). It consists of the rapid deposition of very fine silts, which formed the present day mud drape (Fig. 2b) that infills the major part of the Pertuis Charentais seafloor. Several hypotheses have been proposed to explain this major regional change in sediment grain size that occurred during the last millennium (Chaumillon et al., 2004; Billeaud et al., 2005), namely a decrease in hydrodynamic energy (natural infilling of the bay, land reclamation) and/or an increase in sediment supply (deforestation, climate changes).

\section{Material and methods}

\subsection{Sample processing}

Mollusc skeletal remains were sampled in 98 stations (Fig. 1b), with 49 'B' in the Pertuis Breton and 49 ' $\mathrm{A}$ ' stations in the Pertuis d'Antioche and Marennes-Oléron Bay including the Maumusson Inlet flood delta. Stations were distributed upon a systematic grid with a longitudinal spacing of $2.5 \mathrm{~km}$ and a latitudinal spacing of $2 \mathrm{~km}$. Surface sediment (topmost 15 to $20 \mathrm{~cm}$ layer, roughly corresponding to the Taphonomically Active Zone, Davies et al., 1989) was sampled with a $0.1 \mathrm{~m}^{2}$ van Veen grab, three times in each station, during the FONSOLE cruise in early September 2007. Grab samples were gently sieved on a $1 \mathrm{~mm}$ mesh aboard with seawater. Sieve residues were stored in plastic bags with a mix of seawater and $4 \%$ formaldehyde to preserve soft-bodied organisms.

Once in the laboratory, sieve residues were cleaned with fresh water and stained with Rose Bengal. Stained soft-bodied organisms were sorted and preserved in $70 \%$ ethanol for later identification. For each station, a volume of about $100 \mathrm{~cm}^{3}$ of remaining material (i.e. coarse sediment and biogenic remains larger than $1 \mathrm{~mm}$ ) was taken in each replicate. These subsamples were grouped together (i.e. $300 \mathrm{~cm}^{3}$ ), and mollusc skeletal remains were then sorted. Because of their characteristic morphology (shell colour and/or ornamentation), some fragments were easily recognizable. Their inclusion may distort the taxonomic composition and the relative abundances of species in death assemblages ("Chlamys effect", Kowalewski et al., 2003). In order to avoid this bias, remains were identified only if the hinge lines for bivalves and the apex or peristome for gastropods was intact and if at least $1 / 3$ of the shell was preserved. Gastropods and intact bivalves were counted as 1 individual. Disarticulated valves were counted as 0.5 individual (abundance data). Remains belonging to the same species were grouped together and weighed with a $10 \mathrm{mg}$ precision scale (biomass data).

\subsection{Data analysis}

\subsubsection{Species dataset}

The initial species dataset consisted of a $n$ stations $\times p$ species matrix. Non-indigenous species introduced by man such as Crassostrea gigas, Crepidula fornicata and Ruditapes philippinarum are not expected to appear in the fossil record. Therefore, these three species along with any station where their combined relative abundance exceeded $20 \%$ were removed from the dataset. In order to provide statistically meaningful data, species that matched any of the four following criteria were also removed from the dataset: (1) species represented by a single outlier occurrence whose relative abundance was higher than $Q_{75}+\left(1.5 \times\left(Q_{75}-Q_{25}\right)\right)$ (Tukey, 1977), along with any stations where the relative abundance of these outlier species exceeded $20 \%$, (2) species that occurred in less than 5 sampling stations, (3) species whose maximum relative abundance did not exceed $1 \%$, and 
(4) species for which the distribution of relative abundance values did not match a normal distribution (Shapiro-Wilk test, accepted if $p<0.05$ ). This method of species selection stresses the most abundant, widely occurring, and larger-bodied species in the fauna.

The final species dataset was obtained by combining numerical abundance and biomass data. Biomass-weighted abundance values were calculated as: $\left(\left(a b_{i j} \times m s_{i j}\right){ }_{\Sigma_{i=1}^{n}\left(a b_{i j} \times m s_{i j}\right)}\right) \times 100$ mass values). Hierarchical agglomerative cluster analysis was used to classify sampling stations into homogeneous groups following the taxonomic composition of mollusc death assemblages, and to identify the main species contributing to these groups. Q-mode (stations) and R-mode (species) dissimilarity matrices were computed on square root transformed species dataset, using Morisita-Horn distance. This index was chosen because (1) it is not influenced by sample size and species richness (Magurran, 1988), and (2) it is also highly sensitive to the abundance of the most abundant species (Magurran, 1988), which is an advantage in the case of mollusc death assemblages in which many rare species occur in very low abundances (Kidwell, 2002). Cluster analysis was then carried out on dissimilarity matrices, with UPGMA aggregation method. All statistical analyses were carried out with the R 2.10.0 software (R Development Core Team, 2009), and Morisita-Horn distance was computed with 'fossil' R package (Vavrek, 2010).

\subsubsection{Hydro-sedimentary factors dataset}

The hydro-sedimentary factors dataset consisted of a $n$ stations $\times 3$ variables matrix, the variables being mean grain size, bottom shear stress, and sediment budget (deposition/erosion). Weighted average values (WA) and weighted standard deviation values of the three environment variables were calculated for each species, with relative biomassweighted abundance as weight values. WA is often used to develop transfer functions (e.g. Rossi and Horton, 2009).

During field sampling, a sediment sub-sample was taken in one grab replicate at each sampling station. Grain size analysis was performed in the laboratory by passing dried sediment (100 g for mud and $200 \mathrm{~g}$ for sand), previously sieved on $63 \mu \mathrm{m}$ with fresh water, through 17 stacked sieves with a mesh size ranging from $4000 \mu \mathrm{m}$ to $63 \mu \mathrm{m}$. Mean grain size was calculated in phi units with the GRADISTAT software (Blott and Pye, 2001).

Bottom shear stress values were computed using the 2DH morphodynamic modeling system MORSYS2D (Fortunato and Oliveira, 2004; Bertin et al., 2009). The version used in the present study couples the circulation model ELCIRC (Zhang et al., 2004, www.stccmop.org/CORIE/modeling/elcirc), the spectral wave model SWAN (Booij et al., 1999, www.wldelft.nl/soft/swan) and the sand transport and bottom update model SAND2D (Fortunato and Oliveira, 2004; Bertin et al., 2009). SWAN solves the wave action density balance equation adapted to nearshore zones. SWAN was set up to reproduce wave shoaling and breaking, wave refraction, bottom friction, triad wave-wave interactions and interaction with currents provided by ELCIRC. The water level used in SWAN was extrapolated from the previous ELCIRC run, to guarantee a water level as consistent as possible between the two models. SWAN was forced offshore considering typical energetic wave conditions $\left(\mathrm{Hs}=3.8 \mathrm{~m}, \mathrm{Tp}=11.6 \mathrm{~s}\right.$, direction $\left.=277^{\circ}\right)$, according to the classification of Bertin et al. (2008). Wave parameters were outputted at the nodes of the unstructured grid of ELCIRC and the gradients of radiation stress were computed on this grid using finite differences. ELCIRC uses a finite volume/finite difference Eulerian-Lagrangian algorithm to solve the shallow water equations and, in MORSYS2D, it is used with a single vertical layer $(2 \mathrm{DH})$. ELCIRC was forced along its open boundaries by tidal elevation obtained by interpolation of the regional tidal model of Fortunato et al. (2002) and in the nearshore zones by the gradients of wave induced radiation stress. The non-linear enhancement of bottom friction due to the presence of waves was taken into account through the method of Soulsby 
(1997), considering the skin roughness only, based on median grain size of seafloor sediment (Fig. 2b). The modelling system was run over one neap-spring tidal cycle with a 1 hour morphodynamic time step. Bottom shear stress was archived every 30 minutes to provide mean values at each grid node over the period.

Sediment budget was computed from a bathymetric difference map. Historic bathymetric data (Service Hydrographique et Océanographique de la Marine, SHOM), available on the whole study area, were collected in 1824 using lead line and positioned using horizontal sextant. Recent bathymetric data (SHOM, and local hydrographic office DDE17; Fig. 2a), recorded with monochannel echosounder, include data collected between 1959 and 1983 in areas of moderate sediment mobility, and data collected between 1994 and 2003 in areas of intense sediment mobility and in the navigation channel of La Rochelle Harbour (Fig. 2a). Those two datasets were georeferenced using Arcview software (ESRI) and extensions developed by the SHOM. Digital elevation models (DEM) were computed using 3D-Analyst extension (ESRI) with a grid spacing of $50 \mathrm{~m}$. Because of uncertainties in these elevational data, differences in water depth $\leq|1 \mathrm{~m}|$ were considered to be not different from zero. These data and this methodology have already been used in order to quantify morphological changes in the study area (Allard et al., 2010; Bertin et al., 2004, 2005; Chaumillon et al., 2004, 2008; Weber et al., 2004).

\section{Results}

\subsection{Mollusc death assemblages: taxonomic composition and spatial distribution}

A total of 80 species was identified, including 3 non-indigenous species. The Pacific oyster Crassostrea gigas was found in 31 stations out of 98 but was abundant (more than $20 \%$ of the death assemblage) in only 2 sampling stations. The Manila clam Ruditapes philippinarum was found in only 1 station. The slipper limpet Crepidula fornicata was found in 76 stations out of 98 but was abundant in 14 stations. Among the 77 indigenous species in the initial species dataset, 60 matched the selection criteria for removal from the analysis, and these omitted species constituted $>20 \%$ of individuals in the death assemblages of 26 stations. The final species dataset consisted of a 17 species $\times 72$ sampling stations matrix, including 34 ' $B$ ' stations (Pertuis Breton) and 38 'A' stations (Pertuis d'Antioche and Marennes-Oléron Bay including Maumusson Inlet flood delta).

Hierarchical agglomerative cluster analysis classified species (R-mode) into 8 clusters, and sampling stations (Q-mode) into 9 clusters, including 5 'B' stations in the Pertuis Breton and 4 'A' stations in the Pertuis d'Antioche (Fig. 3). The cross-comparison between Q- and Rmode clusters allowed 6 main mollusc death assemblages to be determined, each characterised by a single dominant species. The first 2 assemblages were inferred to be allochthonous (dominated by shells that have been transported out of their life habitat, sensu Kidwell and Bosence, 1991), based on the well-known qualitative distribution of dominant species in living communities:

- Cerastoderma edule assemblage: cockle shells were found in the subtidal channels of the Marennes-Oléron Bay and to the south of Aix Island. Since this bivalve lives exclusively on intertidal areas, this evidences post-mortem transport of shells from intertidal down to subtidal areas (Fig. 4a).

- Mytilus edulis assemblage: blue mussel shells were found in the most distal parts of the Pertuis Breton. Large sized remains (adult individuals) were found mainly along the Arçay sandspit, close to areas of mussel farming, and along the northeastern coast of Ré Island (Fig. 4b), where abundant mussel beds have been observed on intertidal flats (Poirier, unpublished data).

The 4 remaining death assemblages appear to be within-habitat assemblages (sensu Kidwell and Bosence, 1991), i.e. composed entirely of subtidal species that lived locally (Fig. 3): 
- Spisula subtruncata assemblage is composed of 6 infaunal bivalves, namely Abra nitida, Astarte sulcata, Corbula gibba, Kurtiella bidentata, Nucula nitidosa, Spisula subtruncata and 1 epifaunal bivalve, Aequipecten opercularis. Although Abra nitida was considered by the Rmode cluster analysis as a separate group, it could be attributed to this death assemblage, because the station in which it was found (A33, Fig. 3) belonged to a larger cluster of stations characterised by the Spisula subtruncata assemblage. In the two Pertuis, this assemblage was the most frequent (21 out of 34 'B' sampling stations and 26 out of 38 'A' sampling stations). In 13 'B' stations, S. subtruncata became less abundant, and was replaced by other species such as Corbula gibba (12 stations) or Nucula nitidosa (1 station). In 7 ' $\mathrm{A}$ ' stations, the dominant species was Kurtiella bidentata (2 stations), Corbula gibba (2 stations), Nucula nitidosa (2 stations), and Abra nitida (1 station).

- Anomia ephippium assemblage: includes 3 epifaunal bivalves, Anomia ephippium, Chlamys varia and Parvicardium exiguum, and 1 gastropod, Gibbula cineraria. Although $P$. exiguum is often described as an infaunal species (Tebble, 1966), it retains a byssus as an adult and is apparently largely epibenthic, nestling in depressions or attaching to subaquatic vegetation (Høpner Petersen and Russell, 1971). The assemblage was found in 2 stations in the Pertuis Breton, 2 stations in the Pertuis d'Antioche and 1 in the Marennes-Oléron Bay.

- Donax vittatus assemblage: includes 3 infaunal bivalves, Chamelea striatula, Donax vittatus and Tellina fabula. The assemblage was found in 3 stations in the Pertuis d'Antioche only.

- Spisula solida assemblage: found in 4 sampling stations in the Pertuis Breton only.

\subsection{Hydro-sedimentary factors}

\subsubsection{Sediment mean grain size}

Among the 72 sampling stations selected for data analysis, 46 consisted of mud (mean grain size $>4$ phi), 10 of mixed sand and mud ( 4 to 3 phi), 10 of fine sand ( 3 to 2 phi), 3 of medium sand ( 2 to 1 phi) and 3 of coarse sand to gravel ( $<1$ phi). All the results were consistent with the existing synthetic sedimentological map of the area (Fig. 2b).

\subsubsection{Bottom shear stress}

Bottom shear stress as modelled from data on wave and tidal currents (Fig. 5a) decreases strongly from more than 2 to less than $0.1 \mathrm{~N} . \mathrm{m}^{-2}$ from western wave-dominated coasts to eastern tide-dominated coasts (Fig. 5a). Focusing on the sampled area (mainly tide to mixed tide and wave dominated environment), bottom shear stresses were relatively low. Values

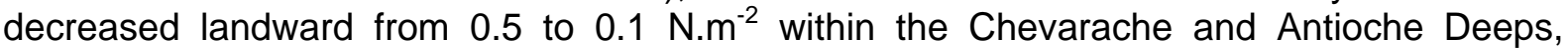
although they were higher in the latter. The slopes of the Chevarache Deep contrasted with relatively higher values on the northern slope (seaward and along the Arçay sandspit). The Inner Domains were characterised by low bottom shear stresses (less than $0.2 \mathrm{~N} . \mathrm{m}^{-2}$ ), although higher values were reported in the Pertuis d'Antioche, because of a better wave propagation due to both deeper bathymetry and a larger entrance. Within the MarennesOléron Bay, bottom shear stresses increased in channels where stronger tidal currents occur. Bottom shear stress reached maximum values on the Longe de Boyard sandbank and above all in the Maumusson Inlet ebb delta, where strong tidal currents, energetic waves and coarse sediments are combined.

\subsubsection{Sediment budget}

The bathymetric difference map (Fig. $5 b$ ) revealed a complex distribution of negative (erosion) and positive (deposition) sediment budget areas within the Pertuis Charentais Sea, 
with values ranging from less than -10 to more than $+10 \mathrm{~m}$. Erosion areas occurred mainly on the slopes of the Chevarache and Antioche Deeps, on the top of the Longe de Boyard sandbank, and at the bottom of the narrow tidal channels of the Marennes-Oléron Bay. Deposition characterised the western edges of the mud drape, which infilled the deepest parts of the Chevarache and Antioche Deeps. Deposition areas also occurred in the Aiguillon Cove, on the edges of the Longe de Boyard sandbank, in the Rade des Trousses tidal channel, and on the slopes of the narrow tidal channels of the Marennes-Oléron Bay.

\subsection{Response of mollusc death assemblages to hydro-sedimentary factors}

\subsubsection{Mean grain size and bottom shear stress}

Weighted average (WA) and weighted standard deviation values of the three factors (mean grain size, bathymetric difference, and bottom shear stress) were calculated for each species, with relative biomass-weighted abundance as weight values. However, values for Cerastoderma edule and Mytilus edulis were not computed, because these two species have undergone obvious post-mortem transport from shellfish farming/or and intertidal areas. Along the increasing gradient from mud to gravel and from low to high shear stresses, the assemblages were set up as following:

- The Spisula subtruncata assemblage (Fig. 6a): WA mean grain size ranged from $4.8 \pm 0.4$ to $4.2 \pm 0.7$ phi and WA bottom shear stress ranged from $0.08 \pm 0.04$ to $0.13 \pm 0.09 \mathrm{~N} \cdot \mathrm{m}^{-2}$. This assemblage, which was the most abundant, had a very wide spatial distribution within the two Pertuis. Its spatial distribution fitted well with that of mud to muddy sand bottoms, corresponding to areas of low bottom shear stress.

- The Anomia ephippium assemblage (Fig. 6b): WA mean grain size ranged from $3.9 \pm 1.2$ to $2.9 \pm 1.1$ phi and WA bottom shear stress ranged from $0.13 \pm 0.06$ to $0.18 \pm 0.06 \mathrm{~N}^{-\mathrm{m}^{-2}}$. The spatial distribution of this assemblage was not related to a specific class of sediment grain size. It was found on mud to gravel bottoms, which explained the large standard deviation related to WA values. It corresponded to areas of low to moderate bottom shear stress.

- The Donax vittatus assemblage (Fig. 6c): WA mean grain size ranged from $3.4 \pm 0.7$ to 3.0 \pm 0.7 phi and WA bottom shear stress ranged from $0.36 \pm 0.25$ to $0.50 \pm 0.25 \mathrm{~N}^{-m^{-2}}$. The spatial distribution of this group corresponded to fine and medium sand bottoms. It was distinctive of the Longe de Boyard sandbank, where stronger shear stress occurs.

- The Spisula solida assemblage (Fig. 6d): WA mean grain size was $2.4 \pm 1.5$ phi and WA bottom shear stress was $0.17 \pm 0.14 \mathrm{~N}^{-2}$. The spatial distribution of this species corresponded to sand to gravel bottoms in the northern Breton Inner Domain mainly, associated to moderate bottom shear stress.

\subsubsection{Sediment budget}

The response of mollusc death assemblages to sediment budget (Fig. 7a) showed a gradient from negative (erosion) to positive (deposition) WA values, which ranged from $-1.1 \pm 2.1 \mathrm{~m}$ (Tellina fabula) to $+1.6 \pm 3.4 \mathrm{~m}$ (Donax vittatus). Two consistent groups of species could be distinguished along this gradient, with significantly different WA values (Kruskal-Wallis test, $p$ $<0.05)$. On one side, the thick-shelled epifaunal bivalves Parvicardium exiguum, Anomia ephippium and Chlamys varia and gastropod Gibbula cineraria, which all belong to the $A$. ephippium assemblage, were characterised by WA values ranging from $-1.0 \pm 1.5$ to $-0.8 \pm$ $1.5 \mathrm{~m}$ (Fig. 7a). They were distinctive of erosion areas (Fig. 7b), in particular in the Breton Inner Domain, in the northern part of Antioche Inner Domain, and to the west of the Marennes-Oléron Bay. On the other side, the thin-shelled infaunal bivalves Nucula nitidosa, Kurtiella bidentata and Abra nitida, which belong to the Spisula subtruncata assemblage, were characterised by WA values ranging from $+0.6 \pm 1.1$ to $+1.6 \pm 2.2 \mathrm{~m}$ (Fig. 7a). They 
were distinctive of deposition areas (Fig. 7c), in particular at the western edges of the mud drape that infills the deepest parts of the Chevarache and Antioche Deeps.

\section{Discussion}

\subsection{Taphonomic inertia}

Taphonomic inertia represents the time needed by a death assemblage to acquire the signature of an ecological change (Kidwell, 2007). Here we quantify the extent of taphonomic inertia in death assemblages by estimating the time passed between the introduction of a non-indigenous mollusc and its first appearance in the death assemblage. Among the nonindigenous molluscs introduced into the Pertuis Charentais Sea (Goulletquer et al., 2002), the slipper limpet Crepidula fornicata is the most promising species for estimating taphonomic inertia. It is non-commercial in Europe, lives in shallow soft-bottom subtidal areas that have been extensively sampled in the present study, and there is relatively good historical knowledge about its population dynamics since the first report of specimens in 1969-1970, in the Marennes-Oléron Bay (Lubet and Le Gall, 1972). The species was not recovered by Hily (1976), who performed a survey of subtidal benthic macrofauna in the whole Pertuis Charentais Sea in 1974 and 1975, suggesting that C. fornicata remained cryptic during at least 5-6 years. Mapping of populations along the tidal channels of the Marennes-Oléron Bay in 1980-1981 (Deslous-Paoli and Massé, 1982), together with population dynamic studies in 1981-1982 (Deslous-Paoli, 1985), have shown that the density of $C$. fornicata locally reached more than from 3000 to 5000 individuals per square meter at that time, indicating an exponential increase of the local population. Significant amounts of dead shells lying on the seafloor of the whole Marennes-Oléron Bay were first mentioned in 1984 (Sauriau, 1987). In 1995, an extensive mapping survey (Sauriau et al., 1998) confirmed these results, showing that dead shells represented on average 25 to $75 \%$ of the total amount of dredged Crepidula fornicata individuals. All together, these results indicate taphonomic inertia on the order of one decade.

The appearance of a species in a death assemblage is a function of its living abundance, fecundity, longevity, and post-mortem durability. Crepidula fornicata combines several features explaining its very low taphonomic inertia: high growth and productivity (DeslousPaoli, 1985), high fecundity (Richard et al., 2006), high dispersal ability owing to planktotrophic larval phase (Viard et al., 2006), absence of predators in the recipient European environments (Thieltges et al., 2004), and a relatively robust shell that can be reused as a substrate for constituting new colonies. Although this estimation, based on a non-indigenous species, might not be generalised to all mollusc species, it suggests a decadal-scale taphonomic inertia, which is consistent with the estimation proposed by Kidwell (2007) on the basis of a statistical meta-analysis. As a consequence, mollusc fossil assemblages in the Pertuis Charentais Sea might be able to acquire a signature of environmental changes rapidly, possibly allowing high-resolution paleoenvironmental reconstructions.

\subsection{Input of allochthonous species}

Subtidal death assemblages recovered from the sampled subtidal shallow waters of the Pertuis Charentais Sea contained very few allochthonous molluscs. A few shells of land snails (Helix aspersa, Limnea sp.), together with abundant plant remains, were found in the B11 and A58 stations, which are located in the Sèvre Niortaise and Charente River mouths, respectively. Although the relative abundance of these species was negligible (much lower than 1\%), this is an example of a mixed assemblage (Kidwell and Bosence, 1991) corresponding to a transition between strictly marine versus terrestrial death assemblages. 
More significant contamination of the subtidal death assemblages was related to intertidal species inputs. The cockle Cerastoderma edule is a representative of the Thorson's Macoma community living on intertidal sandy mudflats. C. edule occurs in large abundance on the tidal flats of the Marennes-Oléron Bay (Sauriau, 1987; Sauriau et al., 1989). Stronger tidal currents during ebb cause the drainage of intertidal mudflats, resulting in a net seaward transport from intertidal down to subtidal areas (Gouleau et al., 2000). This explains why large amounts of dead Cerastoderma edule remains were found in the tidal channels of the bay, close to the mean low water level (Fig. 4a). This post-mortem transport was very likely to be facilitated by the round shape of the $C$. edule shell (Morton, 1964).

Similar interpretation could be proposed for the blue mussel Mytilus edulis. Indeed, M. edulis larvae can settle on both intertidal and subtidal hard substrata, provided that currents are high enough to ensure low turbidity in the water column and sufficient supply of phytoplankton. Shellfish farms in the Pertuis Breton are supplied with mussel larvae caught on artificial collectors (hemp ropes). The large dead remains found along the Arçay sandspit were transported post-mortem from the adjacent mussel farms, which reflects anthropogenic impact on the death assemblage. Wild populations observed along the intertidal flats of the Ré Island originate from larvae that got off either mussel farms or other wild populations. The large $M$. edulis remains sampled on the southwestern slope of the Chevarache Deep (Fig. 4b) were transported post-mortem from those adjacent intertidal mussel beds. In both cases, post-mortem transport from intertidal areas contaminated the subtidal within-habitat death assemblage.

The extent of post-mortem transport of allochthonous intertidal species towards subtidal areas was only of a few 100s to 1000s of meters (minimum linear distance between sampling stations and low tide water mark), which is related to the relatively low bottom shear stress (< $0.5 \mathrm{~N}^{-2} \mathrm{~m}^{-2}$ occurring within the Pertuis Charentais Sea. Such moderate post-mortem transport is consistent with the work of Kidwell and Bosence (1991). Based on a thorough compilation of literature, they suggested that most allochthonous species in nearshore environments are transported from "immediately adjacent habitats", which is the case of the Pertuis Charentais death assemblages, and that "tractive transport is selective, affecting noncementing epifauna", such as Mytilus edulis, or "shallowest burrowing infauna", such as Cerastoderma edule. Allochthonous species transported out of their habitat and included in a death assemblage decrease live-dead agreement (Kidwell and Bosence, 1991). When incorporated to the fossil record, such biased assemblages might lead to erroneous interpretations.

\subsection{Live-dead agreement}

Based on mean relative abundance species, the comparison between this study and quantitative surveys of living infaunal macrofauna in the Pertuis Charentais Sea (Hily, 1976; Sauriau et al., 1989) provided insights into live-dead agreement of the three infaunal death assemblages. Live-dead analysis of the epifaunal Anomia ephippium assemblage was not possible because no similar living community has been described in the Pertuis Charentais Sea so far (Hily, 1976; Sauriau et al., 1989), and because hard substrata represent only a small fraction of subtidal bottoms (Sauriau and Pigeot, in press for the Marennes-Oléron Bay; Fig. 2b). However, based on ecological requirements of the component species (Tebble, 1966; Høpner Petersen and Russell, 1971; Graham, 1988), the Anomia ephippium death assemblage forms a consistent group composed of suspension-feeding bivalves and a gastropod (Gibbula cineraria) that live on hard substrata such as rock flats, pebbles or shells, which explains the large deviation bar related to values of WA mean grain size (Fig. 5b).

The taxonomic composition of the three other infaunal death assemblages closely matched that of living communities in those seafloor types:

- The Spisula subtruncata assemblage corresponded to the Thorson's Abra (=Syndosmya) community, which is composed mainly of suspension and/or deposit-feeding bivalves living on organic-rich mixed sand and mud bottoms in sheltered areas. These muddy-sand to 
muddy subtidal habitats are well-represented within the Pertuis Charentais Sea (Hily, 1976) and dominant species in their respective living assemblages are thin-shelled, deposit-feeding species such as Abra nitida (mean relative abundance $28.3 \%$; Table 1), Nucula nitidosa (25.1\%) and Kurtiella bidentata (13.4\%) together with thicker shell suspension-feeders such as Corbula gibba (7.2\%) and Spisula subtruncata (5.1\%). As already observed in several Holocene sedimentary records studied close to or within the Pertuis Charentais Sea (Gruet and Sauriau, 1994; Poirier et al., 2009), Spisula subtruncata and Corbula gibba are the dominant species in the death assemblage, with mean relative abundances of $46.8 \%$ and $26.5 \%$ respectively, while Abra nitida (1.6 \%), Nucula nitidosa (13.3\%) and Kurtiella bidentata $(4.5 \%)$ are less abundant.

- The Donax vittatus assemblage corresponded to the Thorson's Tellina community, which is composed of suspension-feeding bivalves living on fine sand bottoms exposed to breaking waves. Within the Pertuis Charentais Sea, this assemblage is documented living on fine sand subtidal bottoms submitted to high hydrodynamic conditions (Hily, 1976). The living assemblage is dominated by the thin-shelled Tellina tenuis (28.8\%), which comes along with Tellina fabula and Donax vittatus (both 14.4\%; Table 1). Conversely, the death assemblage was dominated by the thick-shelled bivalve Donax vittatus (68.2\%), while Tellina fabula represented only $2.8 \%$ and Tellina tenuis was not found.

- The Spisula solida assemblage corresponded to a modified Thorson's Venus community. No differences between live and death assemblages exist, because Spisula solida is the sole bivalve belonging to this community (with the exception of the ubiquitous Abra alba and Dentalium entale found in very low abundances; Table 1), which can be locally dominated by soft-bodied organisms such as polychaetes and/or crustaceans like Amphipoda living in medium sands (Hily, 1976).

Following taphonomic expectations (e.g. Behrensmeyer et al., 2005), shell size and thickness are the factors that best explain the mismatch between live and death assemblages of the Pertuis Charentais Sea. Large, thick-shelled suspension-feeding genera such as Spisula, Corbula or Donax occurred in disproportionately larger abundance in the death assemblages, because their shells have an excellent preservation potential compared to smaller thin-shelled species such as Abra, Nucula, Kurtiella or Tellina.

\subsection{Preservation of environmental gradients}

Along the strong environmental gradient from muddy sheltered areas to sandy tide- and wave-exposed areas (Fig. 6), the three infaunal within-habitat death assemblages were arranged in close accordance to the ecological requirements of their component species (Hily, 1976; Sauriau et al., 1989), preserving facies-level differences in species composition. Evidences of even within-habitat post-mortem transport of shells were rare. Some Spisula solida shells have been found on mud bottoms, but the corresponding sampling stations were located very close to the clean medium sands that are the preferred habitat of this bivalve (Hily, 1976; Dauvin, 1997). These few stations containing allochthonous specimens explain the large deviation bar related to values of Spisula solida WA mean grain size (Fig. $6 \mathrm{~d})$. Astarte sulcata, which belonged to the Spisula subtruncata death assemblage, was found in the Chevarache Deep. It is known from shallower areas of the lower circalittoral zone, and thus skeletal remains were very likely to be transported from those offshore deep areas owing to energetic hydrodynamic conditions. Indeed, Idier et al. (2006) have shown that, at the entrance of the Pertuis d'Antioche, the interplay between spring tides and large storms might trigger landward transport of coarse sediment particles up to several millimetres. However, contamination of the within-habitat assemblage in this case was almost non-significant, since $A$. sulcata mean relative abundance was $0.7 \pm 1.3 \%$. Both between-habitat and within-habitat dispersal of shells was thus very limited, the extent of post-mortem transport being of a few 10s to 100s of meters (minimum linear distance between sampling stations and in-situ habitat sediment patches, Fig. 2b). These results support the findings of Tomašových and Kidwell (2009), who found, on the basis of a 
statistical meta-analysis, that death assemblages preserve spatial and environmental gradients similarly to living communities. From those results, it can be expected that mollusc fossil assemblages, in the absence of obvious signs of modification by post-mortem processes, are a correct representation of their immediately adjacent environments.

\subsection{Sediment budget}

5.5.1. Response of death assemblages to sediment budget

Apart from sediment grain size and bottom shear stress, sediment budget also had a significant influence on the composition and spatial distribution of within-habitat death assemblages in the Pertuis Charentais Sea. Two coherent groups of species were distinguished along the gradient from negative (erosion) to positive (deposition) sediment budget (Fig. 7a). The Anomia ephippium death assemblage was distinctive of erosion areas. It was mainly composed of epifaunal species that live attached to hard substrata. Such hard substrata (rock flats, pebbles and large heavy shells) are likely to be more abundant in erosional areas in contrast to soft sediments (muds and sands) that dominate depositional areas. Erosional areas, which foster the concentration or exposure of rocks and gravel, allow colonization by attached epifauna, fixed either with a permanent carbonate plug like Anomia ephippium or with a flexible byssus like Chlamys varia and Parvicardium exiguum. Conversely, thin-shelled Nucula nitidosa, Kurtiella bidentata and Abra nitida, all members of the Spisula subtruncata death assemblage, are distinctive of deposition areas. These brittle bivalves were more abundant in areas of highest historic net sediment accumulation, where they were presumably quickly buried and thus exposed more briefly to processes of postmortem destruction (Kidwell and Bosence, 1991).

Those new results demonstrate the influence of sediment budget on the composition and spatial distribution of death assemblages. In erosion areas (negative budget), death assemblages are dominated by epifaunal species, owing to the availability of hard substrata for attachment by living individuals, whose remains are apparently also quite durable to postmortem reworking. In deposition areas (positive budget), death assemblages are dominated by thin-shelled infaunal species, owing their ecological preference for such soft sedimentary conditions and opportunity for preservation. As a consequence, mollusc fossil assemblages might be used as both ecological and taphonomic indicators of paleosedimentation rate.

\subsubsection{Application to a Holocene mollusc fossil record}

The effectiveness of this hypothesis was tested on a previously published Holocene mollusc fossil record (Poirier et al., 2009) recovered from the Rade des Trousses area (Fig. 2a). The record included a mixed silt and sand body (UT2 stratigraphic unit, Fig. 8) emplaced between $2600 \pm 30$ and $1695 \pm 30$ years uncalibrated years BP (uncal. yr BP), overlain by a fine silt drape emplaced after $630 \pm 30 \mathrm{BP}$ uncal. yr BP. The sharp transition from silty sand to fine silt bottoms did not significantly change the composition of fossil assemblages. Both units were dominated by eurytypic species having large tolerance to variation in bottom facies, especially thick-shelled species such as Spisula subtruncata and Corbula gibba that our analysis here indicates have relatively high preservation potential.

This mollusc fossil record was re-analysed using the cumulated relative abundance of Anomia ephippium, Chlamys varia and Parvicardium exiguum as a proxy for erosion, and the cumulated relative abundance of Nucula nitidosa and Kurtiella bidentata as a proxy for deposition. The sudden increase of the cumulated relative abundance of the latter species indicated an environmental change within the UT4 silt drape. On the basis of very high resolution seismic profiles and sediment cores, the UT4 silt drape was divided in two sub units (from base to top, UT4.1 and UT4.2) split by a high-amplitude reflector correlated with a shelly sand layer (Allard et al., 2010). This reflector corresponded to the epifauna dominated 
shell bed found at the UT4.1 - UT4.2 boundary, composed of Anomia, Chlamys and Parvicardium, which indicates an erosion event that occurred at around $630 \pm 30$ uncal. yr BP. The increased preservation of thin-shelled bivalves (Nucula and Kurtiella) in the UT4.2 sub-unit could be interpreted as an increase of sedimentation rate from this date, as supported by the greater thickness of UT4.2 sub-unit compared to UT4.1 sub-unit in the Rade des Trousses area (Fig. 8).

\section{Conclusion}

Detailed investigations on mollusc death assemblages in the shallow water subtidal Pertuis Charentais Sea strengthen the use of molluscs as paleoenvironmental indicators since:

(1) Death assemblages appear to be able to acquire evidence of ecological changes within years (decadal-scale taphonomic inertia), as deduced from incorporation of shells of nonindigenous Crepidula fornicata.

(2) Allochthonous species in subtidal death assemblages are sourced from immediately adjacent rivers or intertidal mudflats rather than from more distant habitats. Post-mortem transport of these shells, which is caused by river flow or drainage of intertidal mudflats during ebb, is over lateral distances of only a few 100s to 1000s of meters.

(3) The taxonomic composition of both living and death assemblages is similar, indicating that live-dead agreement of within-habitat death assemblages is rather high. Shell durability (shell thickness) may explain most mismatches between the two.

(4) Within-habitat death assemblages accurately preserve gradients in sediment grain size and bottom shear stress, as living communities do. Post-mortem dispersal of shells, owing to relatively low bottom shear stress, is only of a few 10 s to 100 s of meters.

(5) Sediment budget has a significant influence on death assemblages. Erosion creates and/or maintains hard substrate areas available for the settlement of thick-shelled epifaunal species, which are durable to such postmortem conditions, whereas deposition favours the colonisation, rapid burial and preservation of thin-shelled infaunal species. These differences can be exploited in the fossil record to provide insights into paleo-sediment budget of coastal Holocene sedimentary records.

\section{Acknowledgments}

The authors gratefully acknowledge Susan Kidwell and Michal Kowalewski, who agreed to review this manuscript, for their valuable comments and constructive criticism. Field sampling was supported by the FONSOLE project (2006-2008, funded by the Région PoitouCharentes), Ifremer and CNRS. Bathymetric and synthetic sedimentological map were provided by the Service Hydrographique et Océanographique de la Marine (SHOM) and the local hydrographic office Direction De l'Equipement 17 . We gratefully acknowledge Thierry Garlan (SHOM) for the use of these maps. Shellfish farming map was provided by the Direction Des Affaires Maritimes (DDAM) 17 and the DDAM 85. Application of the modelling system MORSYS2D was funded by the Portuguese Fundation for Science and Technology through the research project MADYCOS (Ref. PTDC/ECM/66484/2006). Clément Poirier Ph.D. was supported by a MENRT fellowship from the French government. Special thanks are due to Daphné Grulois, Nicolas Lavesque, Didier Leguay, Nathalie Malet, and the crew of the V/O L'Estran for field sampling, and to Emma Micheneau for grain size analyses. 


\section{References}

Allard, J., Chaumillon, E., Poirier, C., Sauriau, P.-G., Weber, O., 2008. Evidence of former Holocene sea level in the Marennes-Oléron Bay (French Atlantic coast). Comptes Rendus Geosciences 340, 306-314.

Allard, J., Chaumillon, E., Bertin, X., Poirier, C., Ganthy, F., 2010. Secular morphological evolution and Holocene stratigraphy of a macro tidal bay: the Marennes-Oléron Bay (SW France). Bulletin de la Société Géologique de France 181 (2), 151-169.

Aller, J.Y., 1995. Molluscan death assemblages on the Amazon Shelf: Implication for physical and biological controls on benthic populations. Palaeogeography, Palaeoclimatology, Palaeoecology 118 (3-4), 181-212.

Anderson, D.E., Goudie, A.S., Parker, A., 2007. Global environments through the Quaternary. Oxford University Press, Oxford, $392 \mathrm{pp}$.

Behrensmeyer A.K., Fürsich F.T., Gastaldo R.A., Kidwell S.M., Kosnik M.A., Kowalewski M., Plotnick R.E., Rogers R.R., Alroy J., 2005. Are the most durable shelly taxa also the most common in the marine fossil record? Paleobiology 31 (4), 607-623.

Bertin, X., Chaumillon, E., Weber, N., Tesson, M., 2004. Morphological evolution and timevarying bedrock control of main channel at a mixed energy tidal inlet: Maumusson Inlet, France. Marine Geology 204 (1-2), 187-202.

Bertin, X., Chaumillon, E., 2005. New insights in shallow gas generation from very high resolution seismic and bathymetric surveys in the Marennes-Oléron Bay, France. Marine Geophysical Researches 26, 225-233.

Bertin, X., Castelle, B., Chaumillon, E., Butel, R., Quique, R., 2008. Longshore transport estimation and inter-annual variability at a high-energy dissipative beach: St. Trojan beach, SW Oléron Island, France. Continental Shelf Research 28 (10-11), 1316-1332.

Bertin, X., Fortunato, A.B., Oliveira, A., 2009. Simulating morphodynamics with unstructured grids: description and validation of a modeling system for coastal applications. Ocean Modelling 28 (1-3), 75-87.

Billeaud, I., Chaumillon, E., Weber, O., 2005. Evidence of a major environmental change recorded in a macrotidal bay (Marennes-Oléron Bay, France) by correlation between VHR seismic profiles and cores. Geo-Marine Letters 25, 1-10.

Blott, S.J., Pye, K., 2001. GRADISTAT: a grain size distribution and statistics package for the analysis of unconsolidated sediments. Earth Surface Processes and Landforms 26 (11), 1237-1248.

Booij, N., Ris, R.C., Holthuijsen, L.H., 1999. A third generation model for coastal regions - 1 . Model description and validation. Journal of Geophysical Research 104, 7646-7666.

Cadée, G.C., 1968. Molluscan biocoenoses and thanatocoenoses in the Ria de Arosa, Galicia, Spain. Zoologische Verhandelingen 95, 1-121.

Chaumillon, E., Tessier, B., Weber, N., Tesson, M., Bertin, X., 2004. Buried sandbodies within present-day estuaries (Atlantic coast of France) revealed by very high resolution seismic surveys. Marine Geology 211, 189-214.

Chaumillon, E., Weber, N., 2006. Spatial variability of modern incised valleys on the French Atlantic Coast: comparison between the Charente and the Lay-Sèvre incised valleys. Society for Sedimentary Geology Special Publication 85, 57-86.

Chaumillon, E., Bertin, X., Falchetto, H., Allard, J., Weber, N., Walker, P., Pouvreau, N., Wöppelmann, G., 2008. Multi time-scale evolution of a wide estuary linear sandbank, the Longe de Boyard, on the French Atlantic coast. Marine Geology 251 (3-4), 209-223.

Colman, S.M., Baucom, P.C., Bratton, J.F., Cronin, T.M., McGeehin, J.P., Willard, D., Zimmerman, A.R., Vogt, P.R., 2002. Radiocarbon dating, chronologic framework, and changes in accumulation rates of Holocene estuarine sediments from Chesapeake Bay. Quaternary Research 57 (1), 58-70.

Dauvin, J.C. (Ed.), 1997. Les biocénoses marines et littorales françaises des côtes Atlantique, Manche et Mer du Nord, synthèse, menaces et perspectives. Laboratoire de Biologie des Invertébrés Marins et Malacologie, Service du Patrimoine Naturel, Institut 
d'Ecologie et de Gestion de la Biodiversité, Muséum National d'Histoire Naturelle, Paris, 376 pp.

Davies, D.J., Powell, E.N., Stanton, R.J., 1989. Relative rates of shell dissolution and net accumulation - a commentary: can shell beds form by the gradual accumulation of biogenic debris on the sea floor? Lethaia 22, 207-212.

de Montaudouin, X., Sauriau, P.-G., 2000. Contribution to a synopsis of marine species richness in the Pertuis Charentais Sea with new insights in soft-bottom macrofauna of the Marennes-Oléron bay. Cahiers de Biologie Marine 41, 181-222.

Deslous-Paoli, J.-M., Massé, H., 1982. Répartition géographique et structure de population de Crepidula fornicata Linné dans le bassin de Marennes-Oléron en 1981 et 1982. Proceedings of the Council Meeting of the International Council for the Exploration of the Sea, Copenhagen, Denmark.

Deslous-Paoli, J.M., 1985. Crepidula fornicata L. (gastéropode) dans le bassin de MarennesOléron : structure, dynamique et production d'une population. Oceanologica Acta 8 (4), 453460.

Efremov, J.A., 1940. Taphonomy: new branch of paleontology. Pan-American Geologist 74 (2), 81-93.

Flessa, K.W., Cutler, A.H., Meldahl, K.H., 1993. Time and taphonomy; quantitative estimates of time-averaging and stratigraphic disorder in a shallow marine habitat. Paleobiology 19 (2), 266-286.

Fortunato, A.B., Pinto, L., Oliveira, A., Ferreira, J.S., 2002. Tidally generated shelf waves off the western Iberian coast. Continental Shelf Research 22 (14), 1935-1950.

Fortunato, A.B., Oliveira, A., 2004. A modeling system for tidally driven long-term morphodynamics. Journal of Hydraulic Research 42 (4), 426-434.

Fürsich, F.T., Flessa, K.W., 1987. Taphonomy of tidal flat molluscs in the northern Gulf of California; paleoenvironmental analysis despite the perils of preservation. Palaios 2 (6), 543559.

Gouleau, D., Jouanneau, J.-M., Weber, O., Sauriau, P.-G., 2000. Short- and long-term sedimentation on Montportail-Brouage intertidal mudflat, Marennes-Oléron Bay (France). Continental Shelf Research 20, 1513-1530.

Goulletquer, P., Héral, M., 1997. Marine molluscan production trends in France: from fisheries to aquaculture. In: Clyde, J., MacKenzie, L., Victor, J., Burrell, G., Rosenfield, A., Hobart, W.L. (Eds.), The history, present condition, and future of the molluscan fisheries of North and Central America and Europe. U.S. Dept. of Commerce, NOAA, pp. 137-164.

Goulletquer, P., Bachelet, G., Sauriau, P.-G., Noël, P., 2002. Open Atlantic coast of Europea century of introduced species into French waters. In: Leppäkoski, E., Gollasch, S., Olenin, S. (Eds.), Invasive aquatic species of Europe: distribution, impacts and management. Kluwer Academic Publishers, Dordrecht, pp. 276-290.

Graham, A., 1988. Molluscs: Prosobranch and Pyramidellid gastropods. Synopses of the British Fauna 2, 662 pp.

Grizel, H., Héral, M., 1991. Introduction into France of the Japanese oyster (Crassostrea gigas). Journal du Conseil International pour l'Exploration de la Mer 47, 399-403.

Gruet, Y., Sauriau, P.-G., 1994. Paléoenvironnements holocènes du Marais Poitevin (Littoral Atlantique, France) : reconstitution d'après les peuplements malacologiques. Quaternaire 5, 85-94.

Henderson, S.W., Frey, R.W., 1986. Taphonomic redistribution of mollusk shells in a tidal inlet channel, Sapelo Island, Georgia. Palaios 1 (1), 3-16.

Hily, C., 1976. Ecologie benthique des Pertuis Charentais. Unpublished Ph.D. thesis, Université de Bretagne Occidentale, Brest, France, 236 pp.

Høpner Petersen, G., Russell, P.J.C., 1971. Cardium hauniense compared with C. exiguum and C. glaucum. Journal of Molluscan Studies 39, 409-420.

Idier, D., Pedreros, R., Oliveros, C., Sottolichio, A., Choppin, L., Bertin., X., 2006. Contributions respectives des courants et de la houle dans la mobilité sédimentaire d'une plate-forme interne estuarienne. Exemple : le seuil interinsulaire, au large du pertuis d'Antioche, France. Comptes Rendus Geoscience 338, 718-726. 
Johnson, R., 1965. Pelecypod death assemblages in Tomales Bay, California. Journal of Paleontology 39 (1), 80-85.

Kidwell, S.M., Bosence, D.W.J., 1991. Taphonomy and time-averaging of marine shelly faunas. In: Allison, P.A., Briggs, D.E.G. (Eds), Taphonomy: releasing the data locked in the fossil record. Topics in Geobiology. Plenum Press, New York, pp. 115-209.

Kidwell, S.M., 2002. Time-averaged molluscan death assemblages: Palimpsests of richness, snapshots of abundance. Geology 30 (9), 803-806.

Kidwell, S.M., 2007. Discordance between living and death assemblages as evidence for anthropogenic ecological change. Proceedings of the National Academy of Sciences, 104 (45), 17701-17706.

Kowalewski, M., Goodfriend, G.A., Flessa, K.W., 1998. High-resolution estimates of temporal mixing within shell beds: the evils and virtues of time-averaging. Paleobiology 24 (3), 287304.

Kowalewski, M., Carroll, M., Casazza, L., Gupta, N.S., Hannisdal, B., Hendy, A., Krause Jr., R.A., LaBarbera, M., Lazo, D.G., Messina, C., Puchalski, S., Rothfus, T.A., Sälgeback, J., Stempien, J., Terry, R.C., Tomašových, A., 2003. Quantitative fidelity of brachiopod-mollusk assemblages from modern subtidal environments of San Juan Islands, USA. Journal of Taphonomy 1, 43-65.

Lockwood, R., Work, L.A., 2006. Quantifying taphonomic bias in molluscan death assemblages from the upper Chesapeake Bay: patterns of shell damage. Palaios 21 (5), 442-450.

Lubet, P., Le Gall, P., 1972. Recherches préliminaires sur la structure des populations de Crepidula fornicata, Philb., mollusque mésogastéropode. Bulletin de la Société Zoologique de France 97, 211-222.

Magurran, A.E., 1988. Ecological diversity and its measurement. Croom Helm, London, 179 pp.

Miller, A.I., 1988. Spatial resolution in subfossil molluscan remains: implications for paleobiological analyses. Paleobiology 14 (1), 91-103.

Morton, J. E., 1964. Locomotion. In: Wilbur, K.M., Yonge, C.M. (Eds.), Physiology of Mollusca, Vol. I. Academic Press, New York, p. 383-423.

Peacock, J.D., 1993. Late Quaternary marine mollusca as palaeoenvironmental proxies: a compilation and assessment of basic numerical data for NE Atlantic species found in shallow water. Quaternary Science Reviews 12, 263-275.

Poirier, C., Sauriau, P.-G., Chaumillon, E., Allard, J., 2009. Can molluscan assemblages give insights into Holocene environmental changes other than sea level rise? A case study from a macrotidal bay (Marennes-Oléron, France). Palaeogeography, Palaeoclimatology, Palaeoecology 280, 105-118.

R Development Core Team, 2009. R: a language and environment for statistical computing. $R$ Foundation for Statistical Computing, Vienna, Austria. ISBN: 3-900051-07-0. URL: http://www.r-project.org.

Raillard, O., Ménesguen, A., 1994. An ecosystem box model for estimating the carrying capacity of a macrotidal shellfish system. Marine Ecology Progress Series 115, 117-130.

Richard, J., Huet, M., Thouzeau, G., Paulet, Y.M., 2006. Reproduction of the invasive slipper-limpet Crepidula fornicata in the bay of Brest (France). Marine Biology 149, 789-801.

Rossi, V., Horton, B.P., 2009. The application of a subtidal foraminifera-based transfer function to reconstruct Holocene paleobathymetry of the Po Delta, northern Adriatic Sea. Journal of Foraminiferal Research 39 (3), 180-190.

Sanders, H.L., 1958. Benthic studies in Buzzards Bay. I. Animal-sediment relationships. Limnology and Oceanography 3 (3), 245-258.

Sauriau, P.-G., 1987. Les Mollusques non-cultivés du bassin de Marennes-Oléron : quantification et répartition géographique des stocks. Haliotis 16, 527-541.

Sauriau, P.-G., Mouret, V., Rincé, J.-P., 1989. Organisation trophique de la malacofaune benthique non cultivée du bassin ostréicole de Marennes-Oléron. Oceanologica Acta 12 (2), 193-204. 
Sauriau, P.-G., 1991. Spread of Cyclope neritea (Mollusca: Gastropoda) along the northeastern Atlantic coasts in relation to oyster culture and to climatic fluctuations. Marine Biology 109, 299-309.

Sauriau P.-G., Pichocki-Seyfried C., Walker P., de Montaudouin X., Palud C., Héral M., 1998. Crepidula fornicata L. (mollusque, gastéropode) en baie de Marennes-Oléron : cartographie des fonds par sonar à balayage latéral et estimation du stock. Oceanologica Acta 21 (2), 353-362.

Sauriau, P.-.G, Pigeot, J. Contribution à l'inventaire de la macrofaune marine en baie de Marennes-Oléron. Annales de la Société de Sciences Naturelles de Charente-Maritime, in press.

Soulsby, R., 1997. Dynamics of marine sands. Thomas Telford, London, $272 \mathrm{pp}$.

Taldenkova, E., Bauch, H.A., Stepanova, A., Dem'yankov, S., Ovsepyan, A., 2005. Last postglacial environmental evolution of the Laptev Sea shelf as reflected in molluscan, ostracodal, and foraminiferal faunas. Global and Planetary Change 48, 223-251.

Tebble, N., 1966. British bivalve seashells: a handbook identification. British Museum, London, $212 \mathrm{pp}$.

Thieltges, D.W., Strasser, M., van Beusekom, J.E.E, Reise, K., 2004. Too cold to prosperwinter mortality prevents population increase of the introduced American slipper limpet Crepidula fornicata in northern Europe. Journal of Experimental Marine Biology and Ecology 311, 375-391.

Thorson, G., 1957. Bottom communities (sublittoral or shallow shelf). In: Hedgpeth, J.W. (Ed.), Ecology. Geological Society of America, Washington, D.C., pp. 461-534.

Tomašových, A., Kidwell, S.M., 2009. Preservation of spatial and environmental gradients by death assemblages. Paleobiology 35 (1), 119-145.

Tukey, J.W., 1977. Exploratory data analysis. Addison-Wesley, Reading, 688 pp.

Vavrek, M., 2010. fossil: palaeoecological and palaeogeographical analysis tools. R package version 0.2.4.

Viard, F., Ellien, C., Dupont, L., 2006. Dispersal ability and invasion success of Crepidula fornicata in a single gulf: insights from genetic markers and larval dispersal model. Helgoland Marine Research 60, 144-152.

Warwick, R.M., Uncles, R.J., 1980. Distribution of benthic macrofauna associations in the Bristol Channel in relation to tidal stress. Marine Ecology Progress Series 3, 97-103.

Weber, N., Chaumillon, E., Tesson, M., Garlan, T., 2004. Architecture and morphology of the outer segment of a mixed tide and wave-dominated-incised valley, revealed by HR seismic reflection profiling: the paleo-Charente River, France. Marine Geology 207 (1-4), 17-38.

Zhang, Y., Baptista, A.M., Myers, E.P., 2004. A cross-scale model for 3D baroclinic circulation in estuary-plume-shelf systems: I. Formulation and skill assessment. Continental Shelf Research 24 (18), 2187-2214.

Zinke, J., Reijmer, J.J.G., Taviani, M., Dullo, W.-C., Thomassin, B., 2005. Facies and faunal assemblage changes in response to the Holocene transgression in the Lagoon of Mayotte (Comoro Archipelago, SW Indian Ocean). Facies 50, 391-408.

Zuschin, M., Oliver, P.G., 2003. Fidelity of molluscan life and death assemblages on sublittoral hard substrata around granitic islands of the Seychelles. Lethaia 36, 133-150.

Table

Table 1. Mean relative abundance of the living benthic infaunal mollusc communities sampled in the Pertuis Charentais Sea (modified from Hily, 1976), in relation with seafloor sediment types. Bold text indicates species selected in the present study.

Seafloor sediment Species Mean relative abundance

(\%)

Mud and sandy mud Abra nitida

28.3 


$\begin{array}{lrr} & \text { Nucula nitidosa } & 25.1 \\ & \text { Kurtiella bidentata } & 13.4 \\ & \text { Philine aperta } & 11.2 \\ \text { Corbula gibba } & 7.2 \\ \text { Spisula subtruncata } & 5.1 \\ & \text { Dentalium novemcostatum } & 2.9 \\ & \text { Pandora inaequivalvis } & 1.3 \\ \text { Turritella communis } & 1.3 \\ & \text { Phaxas pellucidus } & 1.3 \\ & \text { Barnea candida } & 1.1 \\ & \text { Abra alba } & 1.1 \\ & \text { Macoma baltica } & 0.5 \\ & & \\ & \text { Tellina tenuis } & 28.8 \\ \text { Tellina fabula } & 14.2 \\ & \text { Donax vittatus } & 14.2 \\ & \text { Mactra corallina } & 14.2 \\ & \text { Abra alba } & 9.5 \\ & \text { Pandora inaequivalvis } & 9.5 \\ & \text { Chamelea striatula } & 4.7 \\ & \text { Spisula solida } & 4.7 \\ & & \\ & \text { Spisula solida } & 85.5 \\ & \text { Abra alba } & 9.8 \\ & \text { Dentalium entale } & 4.7\end{array}$

\section{Figures}

Fig. 1. Location of the study area. (a) Map of France, indicating the location of the Pertuis Charentais Sea. (b) Map of the Pertuis Charentais Sea, indicating the location of the 98 sampling stations, the toponyms cited in the text, the mean low water level at spring tides (black line) that delineates the intertidal area, and the shellfish farms (solid vertical black lines for mussel farms, dashed horizontal black lines for oyster farms).

Fig. 2. (a) Recent bathymetric map of the Pertuis Charentais Sea (data provided by the Service Hydrographique et Océanographique de la Marine, SHOM). Intervals of time indicated on the map correspond to the dates of collection of recent bathymetric data. (CD: Chevarache Deep, AD: Antioche Deep, BID: Breton Inner Domain, AID: Antioche Inner Domain, LdB: Longe de Boyard sandbank, RdT: Rade des Trousses tidal channel). (b) Synthetic sedimentological map of the Pertuis Charentais Sea (data provided by the SHOM). Small black squares indicate the location of the 98 sampling stations.

Fig. 3. Q-mode (stations) and R-mode (species) hierarchical agglomerative cluster analysis performed on Morisita-Horn dissimilarity matrix with UPGMA aggregation method. Greyshaded areas indicate groups of clusters.

Fig. 4. Spatial distribution of the two allochthonous death assemblages identified in Fig. 3. (a) Map of the relative abundance of Cerastoderma edule. Black line represents the mean low water level at spring tides, which delineates intertidal areas. (b) Map of the relative abundance of Mytilus edulis. Hatched areas correspond to mussel farming. 
Fig. 5. (a) Spatial interpolation map of mean values provided by the modelling of bottom shear stress with typical energetic wave conditions $(\mathrm{Hs}=3.8 \mathrm{~m}, \mathrm{Tp}=11.6 \mathrm{~s}$, direction = $277^{\circ}$ ). Hatched white areas correspond to areas where the model failed to correctly reproduce hydrodynamic behaviour in very shallow water. (b) Sediment budget map, computed by the difference between historical (1824) and recent (from 1959 to 2003) bathymetric maps (SHOM data). Intervals of time indicated on the map correspond to the dates of collection of recent bathymetric data. Small black squares indicate the location of the 98 sampling stations.

Fig. 6. Response of within-habitat death assemblages to mean grain size and bottom shear stress. For each assemblage, from left to right, are indicated the plot of WA mean grain size (phi units) versus WA bottom shear stress $\left(\mathrm{N}^{\mathrm{m}} \mathrm{m}^{-2}\right)$, the cumulated relative abundance of the species belonging to the assemblage superimposed on synthetic sedimentological map (see Fig. $2 b$ for legend), and on bottom shear stress map (see Fig. 5a for legend). Four letters abbreviations correspond to species names. (a) The Spisula subtruncata assemblage (Anit: Abra nitida, Aope: Aequipecten opercularis, Asul: Astarte sulcata, Cgib: Corbula gibba, Kbid: Kurtiella bidentata, Nnit: Nucula nitidosa and Ssub: Spisula subtruncata), (b) the Anomia ephippium assemblage (Aeph: Anomia ephippium, Cvar: Chlamys varia, Gcin: Gibbula cineraria, Pexi: Parvicardium exiguum), (c) the Donax vittatus assemblage (Cstr: Chamelea striatula, Dvit: Donax vittatus, Tfab: Tellina fabula) and (d) the Spisula solida assemblage (Ssol).

Fig. 7. (a) Response of autochthonous death assemblages to sediment budget. Four letters abbreviations correspond to species names (see Fig. 6 caption for detailed list). Thin black lines correspond to weighted standard deviation values. (b) Cumulated relative abundance of the thick-shelled epifaunal bivalves Chlamys varia, Anomia ephippium, and Parvicardium exiguum and gastropod Gibbula cineraria, superimposed on sediment budget map. (c) Cumulated relative abundance of the thin-shelled infaunal bivalves Nucula nitidosa, Kurtiella bidentata, and Abra nitida, superimposed on sediment budget map.

Fig. 8. Mollusc fossil record from the Marennes-Oléron Bay, modified from Poirier et al. (2009), indicating from left to right: depth in meters (French reference level NGF, 0 m being the mean tidal level at Marseilles), stratigraphic units, radiocarbon dating (uncalibrated years BP), simplified grain size log, cumulated relative abundance of Anomia ephippium, Chlamys varia and Parvicardium exiguum, and cumulated relative abundance of Nucula nitidosa and Kurtiella bidentata. Light grey shade in abundance plots corresponds to sediments not sampled. 


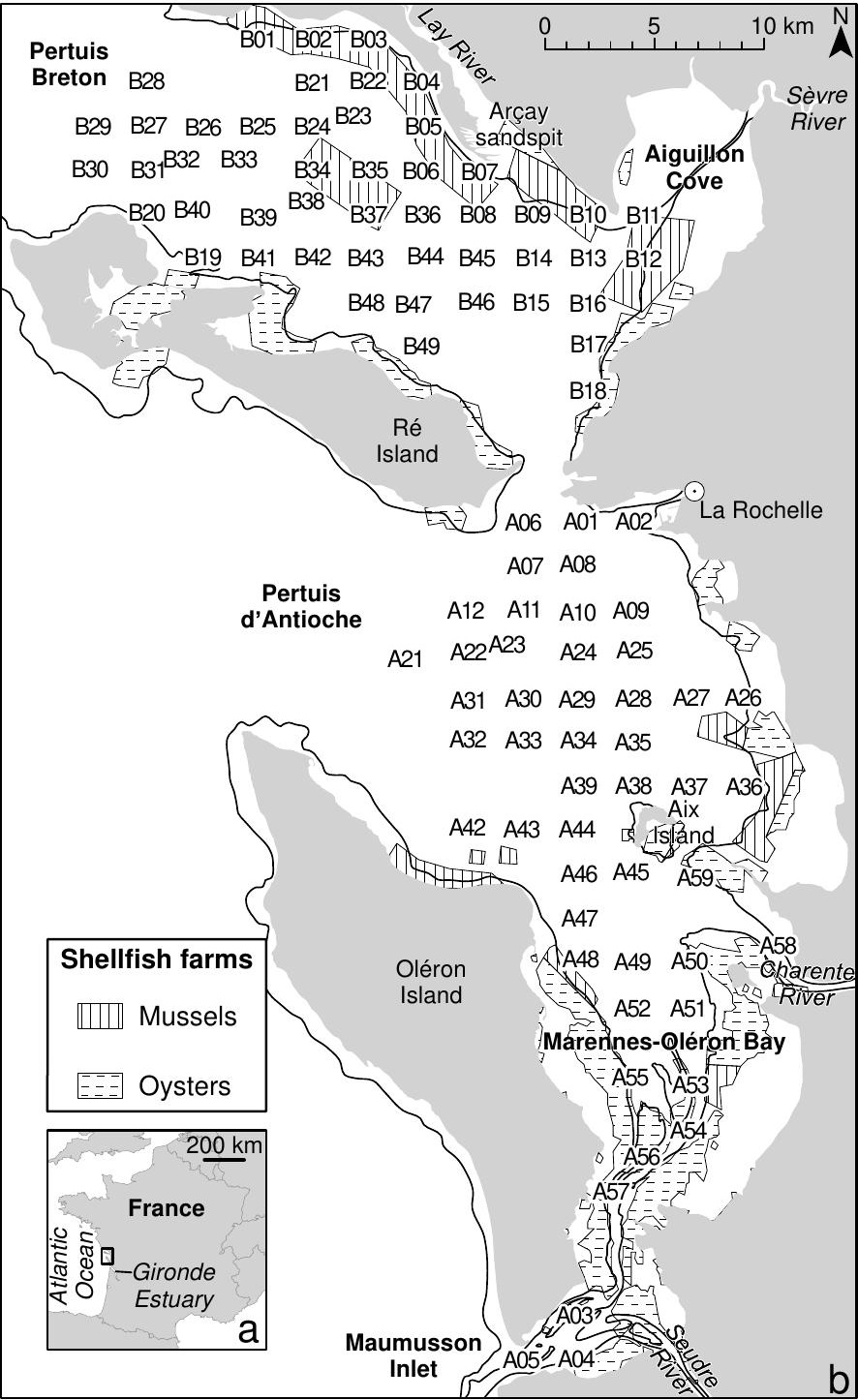




\section{Pertuis d'Antioche and Marennes-Oléron Bay}

Relative abundance

- $\bigcirc \bigcirc$

$>0 \% \quad 25 \% \quad 50 \% \quad 75 \% \quad 100 \%$

Similarity (\%)

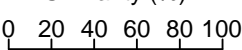

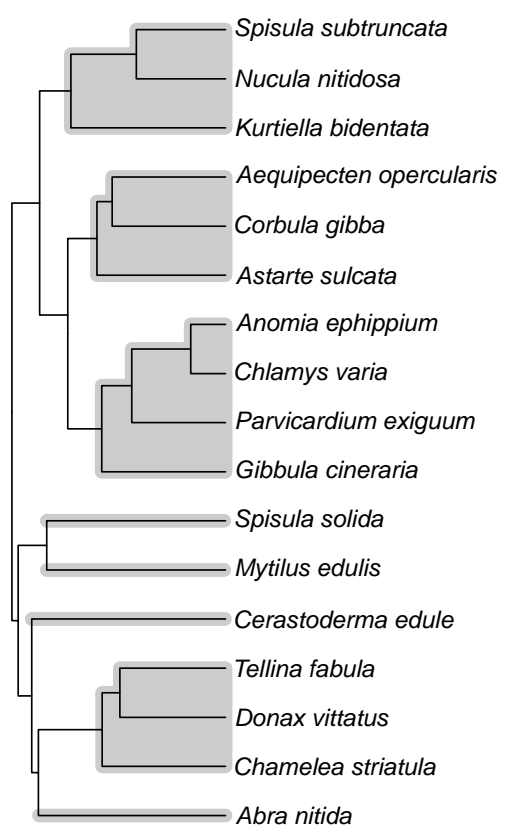

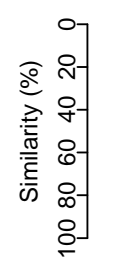

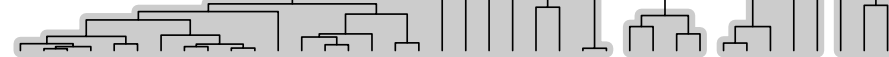

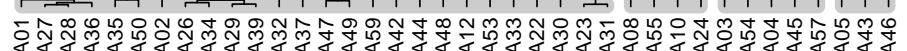
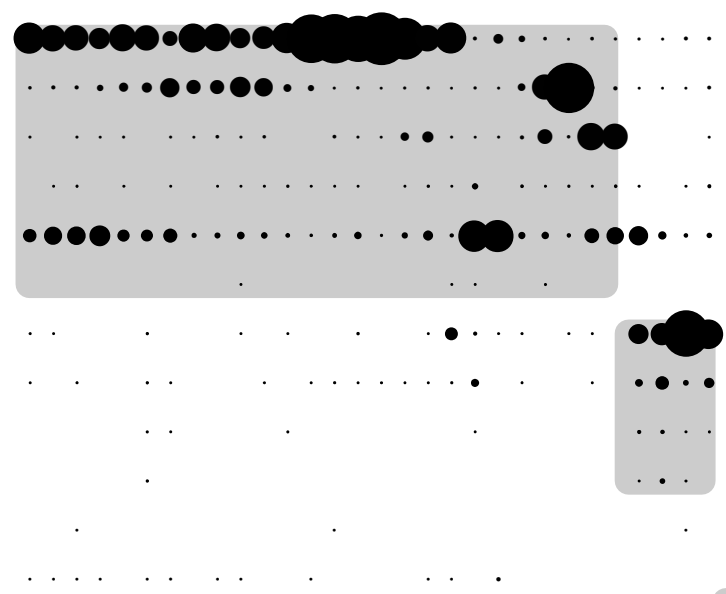

Pertuis Breton

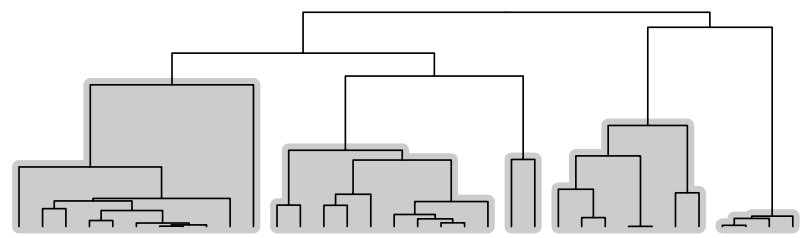

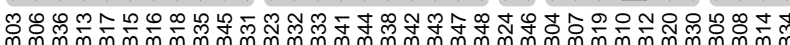

○

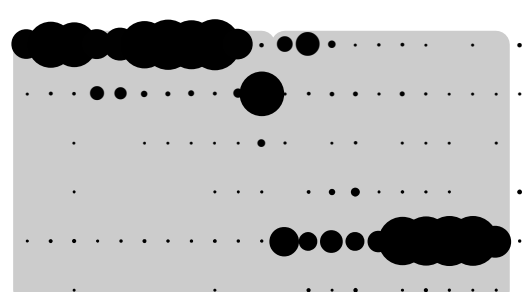

$\bullet \bullet \circ .$. $\because$

-
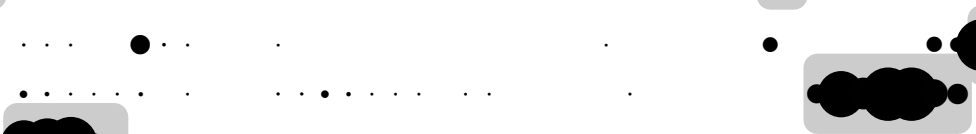

๑. 

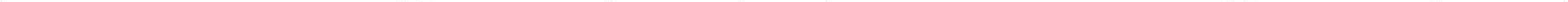


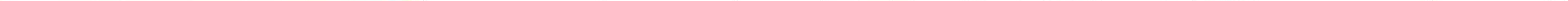


Thick-shelled epifauna

(Chlamys varia, Anomia ephippium, Parvicardium exiguum, Gibbula cineraria)

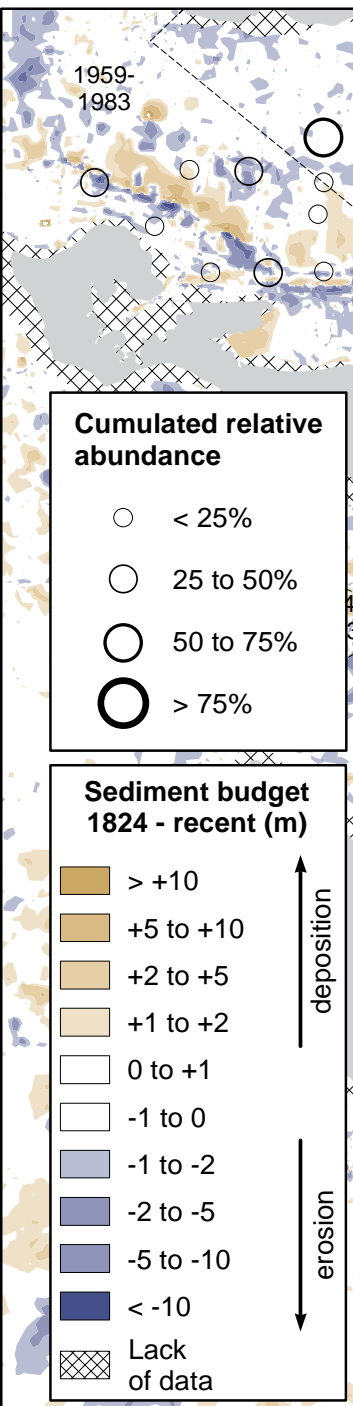
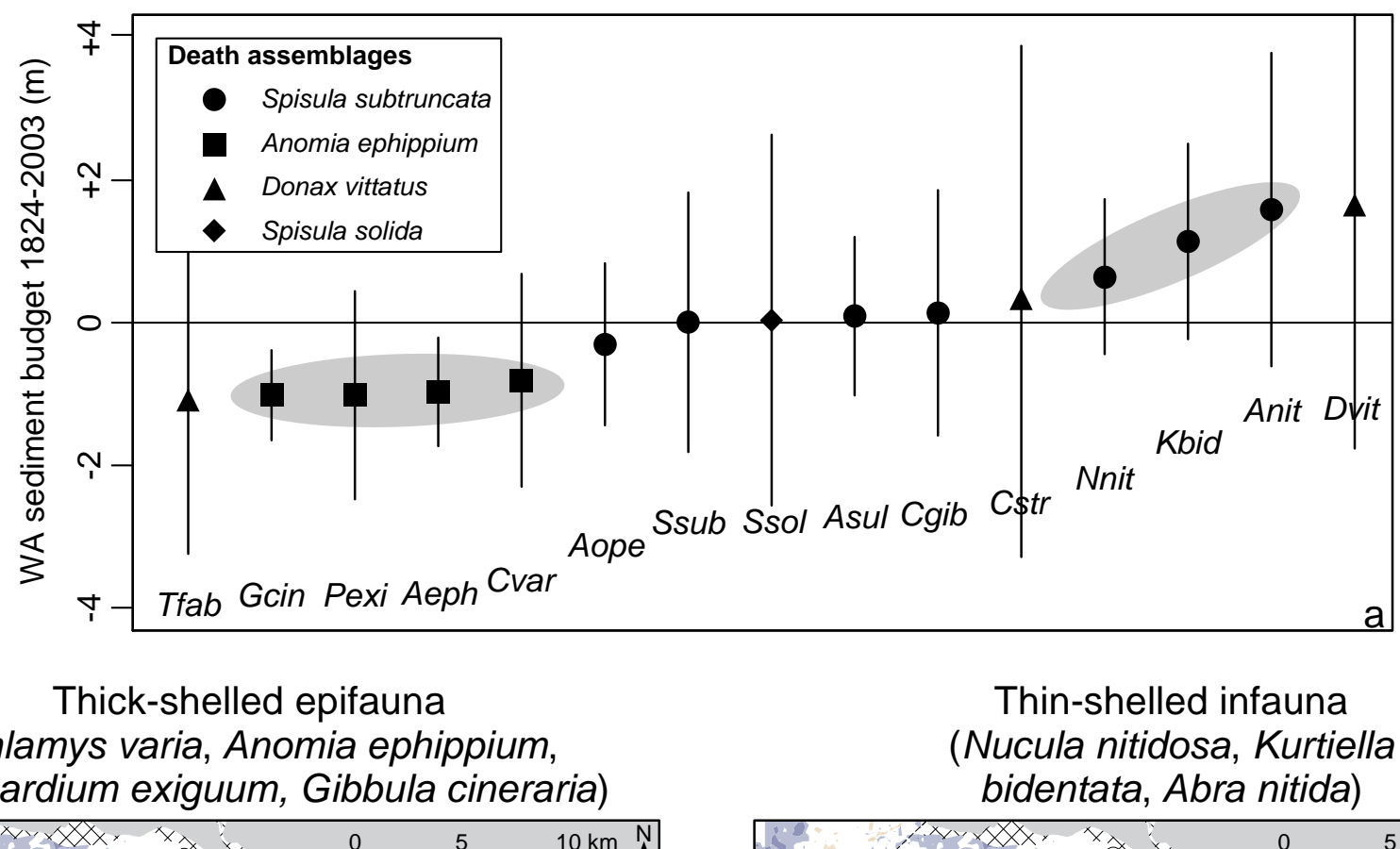

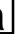


